\title{
Ornamental Pepper Growth and Fruiting Response to Uniconazole Depends on Application Time
}

\author{
Terri Woods Starman \\ Department of Ornamental Horticulture and Landscape Design, University of \\ Tennessee, Knoxville, TN 37901-1071
}

Additional index words. Capsicum annuum, growth regulators, pinching, Sumagic, XE-1019

\begin{abstract}
This study investigated the effects of concentration and application time of uniconazole as a spray for single- or double-pinched ornamental pepper (Capsicum annuum L. 'Holiday Cheer'). Concentrations from 5.0 to $15.0 \mathrm{mg} \cdot \mathrm{liter}^{-1}$ gave adequate height control, except that $15.0 \mathrm{mg} \cdot \mathrm{mlter}^{-1}$ reduced height excessively when applied 8, but not 10, weeks after sowing. Increasing uniconazole concentration increased red fruit percentage when applied at 10 , but not 8 , weeks after sowing. These results indicate that the later application was beneficial and may lessen the overdosing problem associated with triazole growth regulators. Chemical name used: (E)-(S)-1-(4-chlrophenyl)-4,4-dimethyl-2-(1,2,4-triazol-1-yl)-pent-1-ene-3-oll(uniconazole).
\end{abstract}

Ornamental peppers grown in 0.4-liter pots are popular in Europe and are gaining popularity in the United States (Armitage and Hamilton, 1987). Merits of ornamental pepper as a potted plant include easy seed propagation, relatively short cropping time, heat and drought tolerance, excellent keeping quality (Harbaugh and Waters, 1979), and fruit production until frost following transplanting outdoors. One drawback of growing ornamental pepper has been the need for a single or double pinch (Ball, 1985; Hammer, 1980) to produce compact, well-branched, and heavily fruited plants. Past research with growth regulators on ornamental peppers has focused on eliminating the need for pinching.

(2-Chloroethyl)phosphonic acid(ethephon), applied as a foliar spray at $300 \mathrm{mg} \cdot \operatorname{liter}^{-1} 2$ weeks post-pinch, substituted for pinching by hand in increasing the lateral branches of 'Teno' ornamental pepper, but delayed flowering and reduced fruit production (Khademi and KhoshKhui, 1977). N-(phenylmethyl)-1H-purin-6amine (BA) or 1H-indole-3-acetic acid (IAA) likewise had no desirable effect on the ornamental characteristics of treated plants. Dikegulac-sodium reduced plant height and increased branching of chili pepper (C. annuиm), but reduced yield because fruit did not mature before the first fall frost (Matta, 1984).

Most ornamental peppers are grown in 10cm (0.4-liter) pots (Ball, 1985). The objective of this research was to determine the uniconazole foliar spray concentration and application time required to reduce plant height of 'Holiday Cheer' ornamental pepper to 15 to

Received for publication 20 Oct. 1992. Accepted for publication 22 Apr. 1993. I thank Arnold Saxton, Agricultural Experiment Station, Univ. of Tennessee, for assistance in data analysis. The cost of publishing this paper was defrayed in part by the payment of page charges. Under postal regulations, this paper therefore must be hereby marked advertisement solely to indicate this fact.
$20 \mathrm{~cm}$, the height range considered to be in proportion to a 10-cm pot (Sachs et al., 1976). I also compared single and double pinching with uniconazole.

'Holiday Cheer' seeds (Ball Seed, West Chicago, Ill.) were sown 3 May 1990 in rows in bedding plant flats containing Jiffy Mix (Jiffy Products, West Chicago, Ill.) and placed under intermittent mist until emergence. On 21 May, one seedling was transplanted into each 0.4-liter clay pot, which contained ProMix BX (Premier Brands, New Rochelle, N.Y.). Plants were grown in a 24/18C (venting/night set points) glasshouse and, commencing 31 May, fertilized at each irrigation with $20 \mathrm{~N}$ 4.4P-16.6K. The standard feeding program was used-apply $\mathrm{N}$ at $200 \mathrm{mg}$-liter' until fruit set, then reduce the fertilizer concentration by half until market time. Fruit set was delayed by $\approx 3$ weeks by double pinching rather than single pinching; thus, individual plants were fertilized as needed.

On 11 June (6 weeks after sowing), all plants, including controls, were single-pinched to three nodes. Two weeks later, when new growth was 5 to $8 \mathrm{~cm}$ long, half were doublepinched. At this time, laterals were pinched back to two or three nodes. A no-pinch control was not included in the experiment because the commercial recommendation is to pinch plants at least once (Nau, 1989).

Table 1. Analysis of variance for effect of single or double pinch and uniconazole application time and concentration on plant and fruit characteristics of 'Holiday Cheer' ornamental pepper.

\begin{tabular}{|c|c|c|c|c|c|}
\hline \multirow[b]{2}{*}{ Source } & \multicolumn{2}{|c|}{ Plant } & \multicolumn{2}{|c|}{ Red fruit } & \multirow[b]{2}{*}{$\begin{array}{c}\text { Total fruit } \\
\text { (no.) }\end{array}$} \\
\hline & $\begin{array}{l}\text { Diam } \\
(\mathrm{cm})\end{array}$ & $\begin{array}{c}\mathrm{Ht} \\
(\mathrm{cm})\end{array}$ & $\begin{array}{l}\text { Proportion } \\
\text { of total }(\%)\end{array}$ & $\begin{array}{l}\text { Diam } \\
(\mathrm{mm})\end{array}$ & \\
\hline Pinch (P) & NS & NS & . $* *$ & NS & $*$ \\
\hline Time (T) & $*$ & $*$ & $* *$ & NS & NS \\
\hline Concentration (C) & $* * *$ & $* * *$ & NS & NS & $* * *$ \\
\hline $\mathrm{P} \times \mathrm{T}$ & NS & NS & $* * *$ & $* *$ & $* *$ \\
\hline $\mathrm{P} \times \mathrm{C}$ & NS & NS & NS & NS & $* *$ \\
\hline $\mathrm{T} \times \mathrm{C}$ & NS & $*$ & $*$ & NS & $* *$ \\
\hline $\mathrm{P} \times \mathrm{T} \times \mathrm{C}$ & NS & NS & NS & NS & $* * *$ \\
\hline
\end{tabular}

Growth retardant treatments were applied once, either 8 (date of double pinch) or 10 weeks after sowing, to single- and doublepinched plants. Uniconazole concentrations of $0,2.5,5.0,10.0$, and $15.0 \mathrm{mg} \cdot$ liter $^{-1}$ were applied at $204 \mathrm{ml}$ of solution $/ \mathrm{m}^{2}$ of bench space. Control plants were sprayed with water only. Single-pinched plants were considered marketable on 7 Sept., and those doublepinched, on 28 Sept.

Treatments were arranged as a $2 \times 2 \times 5$ factorial with two pinching treatments (single pinch and double pinch), two growth retardant application times, and five uniconazole concentrations using 10 single-plant replicates in a completely randomized design. Analysis of variance and orthogonal polynomial contrasts were used in data analyses (SAS Proc GLM; SAS Institute, Cary, N.C.). Controls were included in polynomials as zero concentration of uniconazole. Since the uniconazole concentrations were not equally spaced, appropriate coefficients for contrasts were determined. For variables in which the three-way interaction was significant, concentration polynomials were compared among pinch and time treatments. The data for red fruit percentage were tested for normality before analysis.

Data taken at harvest included plant height and diameter, count of red and nonred fruit, and red fruit diameter. Plant height was measured from the bottom of the pot to the top of the plant, and pot height $(10 \mathrm{~cm})$ was subtracted from the total measurement. Plant diameter was measured across the top of the plant. The count of red and nonred fruit and red fruit diameter were determined on five plants per treatment. The diameters of three randomly selected red fruits were measured per plant.

There were no interactions among the treatment factors for plant diameter (Table 1). As uniconazole concentration increased from 0 to 15 mg-liter', plant diameter decreased linearly by $20 \mathrm{~cm}$, from 61 to $41 \mathrm{~cm}$. Plant diameter was greater when uniconazole was applied at 10 than at 8 weeks after sowing (55 vs. $53 \mathrm{~cm}$ ) regardless of concentration.

Single or double pinching did not affect plant height (Table 1). There was an interaction between application time and uniconazole concentration for plant height. As concentration increased, height decreased, but the linear decrease with application at 8 weeks was greater than at 10 weeks, and application at week 8 also resulted in a positive quadratic 

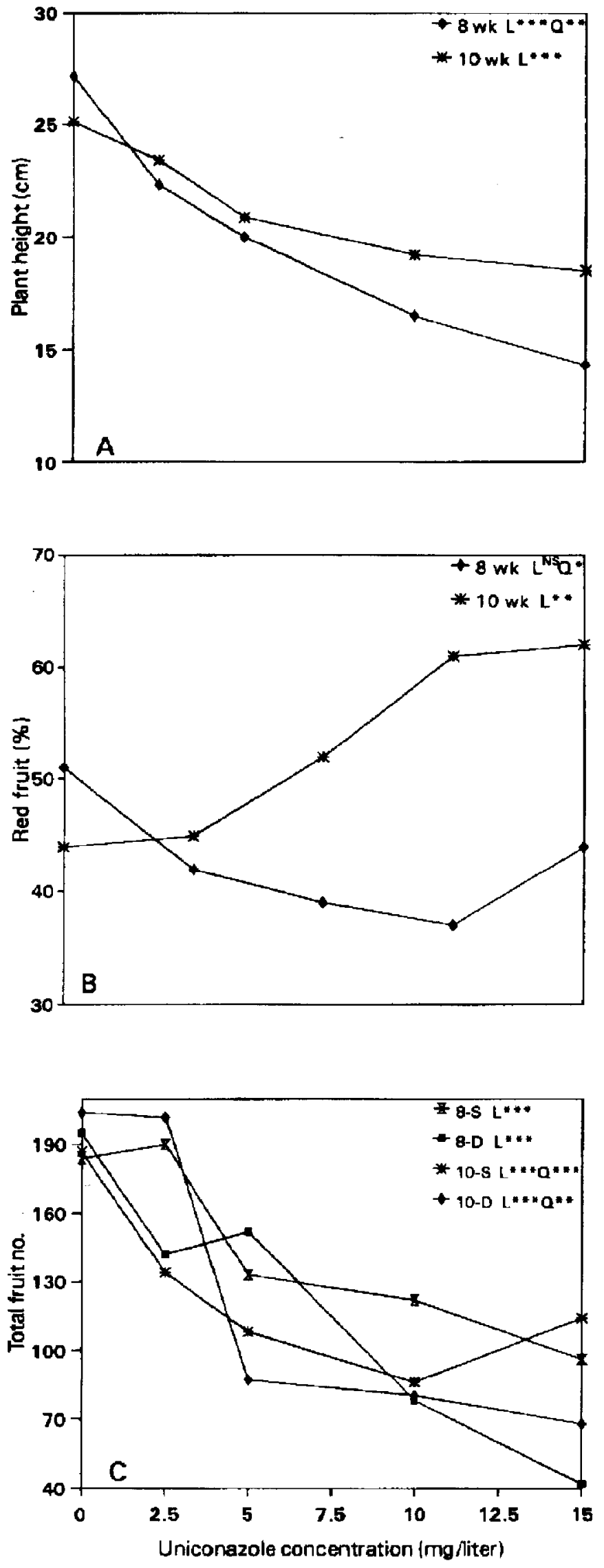

Fig. 1. Effects of uniconazole foliar spray concentration $\left(\mathrm{mg} \cdot \mathrm{liter}{ }^{-1}\right)$ on 'Holiday Cheer' ornamental pepper. (A) Interaction with application time (8 or 10 weeks after sowing) on plant height (in centimeters); SE $=0.99$. (B) Interaction with application time on red fruit percentage; $S E=5.08$. (C) Interaction with application time and pinch treatment ( $\mathrm{S}$ is single pinch, $\mathrm{D}$ is double pinch) on total fruit count; $\mathrm{SE}=8.30$. response (Fig. 1A). The decrease in height was greatest at $15 \mathrm{mg} \cdot$ liter $^{-1}$, when the chemical was applied at 8 weeks. These plants appeared stunted (14 cm tall).

Two-way interactions occurred between uniconazole application time and concentration and between pinch and application time treatments for percentage of red fruit (Table 1). Increasing uniconazole concentration linearly increased the red fruit percentage when applied at 10 weeks, but at 8 weeks, the red fruit percentage had a quadratic response, with aminimum at intermediate concentrations (Fig. 1B). Red fruit percentage did not differ with application time for double-pinched plants (43\% vs. $40 \%$ for 8 vs. 10 weeks) but increased with delayed application on single-pinched plants $(42 \%$ vs. $66 \%)$.

There was an interaction between pinch and uniconazole application time for red fruit diameter (Table 1). However, the difference was only $1 \mathrm{~mm}$ and, therefore, commercially insignificant (data not shown).

The total fruit count showed a three-way interaction (Table 1), with greater linear reduction as concentration increased for doublepinched as compared to single-pinched plants (Fig. 1C). Interaction also was caused by the response being quadratic when uniconazole was applied at 10 weeks, but not at 8 weeks, regardless of pinching treatment.

In my experiments, 'Holiday Cheer' ornamental pepper plants grew out of proportion to their $10-\mathrm{cm}$ pots unless they were treated with uniconazole. The degree of height control depended on the application time of uniconazole. Plantheight of $\approx 15$ to $20 \mathrm{~cm}$ was achieved with uniconazole concentrations of 5.0 or 10.0 $\mathrm{mg} \cdot$ liter $^{-1}$ applied at 8 weeks and 10.0 or 15.0 $\mathrm{mg} \cdot \mathrm{liter}^{-1}$ applied at 10 weeks. Excessive height control occurred when $15.0 \mathrm{mg} \cdot$ liter $^{-1}$ was used at 8 weeks.

These results are similar to results with chrysanthemum [Dendranthema $\times$ grandiflorum (Ramat.) Kitamura], whereuniconazole caused adequate height control applied 4 weeks after pinching, but resulted in excessive reductions when applied on the pinch date or 2 weeks later (Gilbertz, 1992). This study's reduced plant canopy at 8 weeks compared to 10 weeks may have resulted in a greater response due to more chemical contact with soil and stems. Triazoles are absorbed by plant stems and roots and move acropetally via the xylem to growing shoots (Davis et al., 1988). A common problem with triazole application is overdosing, which could be lessened by applying the chemical later in the crop cycle when axillary branches are more fully developed (Gilbertz, 1992).

Round-fruited ornamental pepper such as 'Holiday Cheer', cultured to enhance red-fruit production, could increase the diversity of crops grown for the Christmas market. Amount of red compared to other fruit colors (green, yellow, orange, or purple) increased as uniconazole concentration increased when the application was delayed to the later development stage (Fig. 1B). This observation suggests that uniconazole may have an effect on fruit ripening when timed to the development 
stage. Later application combined with a single pinch was preferred to avoid delay in fruit ripening and increase fruit yield.

\section{Literature Cited}

Armitage, A. and B. Hamilton. 1987. Ornamental peppers: A hot new crop. Greenhouse Grower 5(1):92-94.

Ball, V. 1985. Ornamental pepper and Christmas cherry, p. 601-603. In: V. Ball (ed.). Ball red book. Reston Publishing Co., Reston, Va.
Davis, T.D., G.L. Steffens, and N. Sankhla. 1988 Triazole plant growth regulators. Hort. Rev. 10:63-105.

Gilbertz, D.A. 1992. Chrysanthemum response to timing of paclobutrazol and uniconazole sprays. HortScience 27:322-323.

Hammer, P.A. 1980. Other flowering pot plants, p. 442445. In: R.A. Larson (ed.). Introduction to floriculture. Academic, New York.

Harbaugh, B.K. and W.E. Waters. 1979. Evaluation of flowering potted plants under simulated home conditions. HortScience 14:743-745.

Khademi, M. and M. Khosh-Khui. 1977. Effect of growth regulators on branching, flowering, and fruit development of ornamental pepper (Capsicum annuum L.). .I. Amer. Soc. Hort. Sci. 102:796-798.

Matta, F.B. 1984. Effects of hand-pinching and dikegulac-sodium sprays on Capsicum annuиm. HortScience 19:284-285.

Nau, J. 1989: Ball culture guide. 1st ed. George J. Ball, W. Chicago, Ill.

Sachs, R.M., A.M. Kofranek, and W.P. Hackett. 1976. Evaluating new pot plant species. Florists Rev. 159(4116):35-36, 80-84. 